\title{
THEORETICAL ISSUES ASSOCIATED WITH THE EVALUATION OF THE TECHNICAL CONDITION OF AVIONIC HYDRAULIC DRIVES ON THE BASIS OF INFORMATION RECEIVED FROM MEANS FOR UNBIASED FLIGHT CONTROL OF AIRCRAFTS
}

\author{
TEORETYCZNE ASPEKTY OCENY STANU \\ TECHNICZNEGO LOTNICZEGO NAPECU \\ HYDRAULICZNEGO NA PODSTAWIE INFORMACJI ZE \\ ŚRODKÓW OBIEKTYWNEJ KONTROLI LOTU
}

\author{
Leszek Ulanowicz \\ Air Force Institute of Technology \\ e-mail: leszek.ulanowicz@itwl.pl
}

\begin{abstract}
The paper explains how to benefit from information acquired from means for unbiased flight control and to use it for technical condition assessment demonstrated by the aircraft. There are two control parameters that are provided by the means of unbiased flight control and convey the highest trustworthiness and troubleshooting content. The first one is the duration of pressure drop across the avionic hydraulic drive after switching the driving unit off with the span from the upper measured limit to the lower limit. The second one is the total time of the cycle when the pressure drops below the specific threshold and then is restored to that threshold during a hydraulic motor movement (an on-board aircraft actuator). The suggested method enables real time evaluation of technical condition attributable to avionic hydraulic drives, is quick and entails no additional expenses.
\end{abstract}

Keywords: technical condition, avionic hydraulic drive, hydraulic plunger and barrel mating assembly, aircraft, control parameter, wear and tear process.

Streszczenie: Celem pracy jest przedstawienie możliwości wykorzystania do oceny stanu technicznego lotniczego napędu hydraulicznego metody polegajacej na wykorzystaniu informacji ze środków obiektywnej kontroli lotu. Największa wiarygodność oraz wartość diagnostyczna maja dwa parametry kontrolne uzyskane ze środków obiektywnej kontroli lotu. Pierwszy to czas spadku ciśnienia $w$ lotniczym napędzie hydraulicznym od górnej wartości pomiarowej do dolnej wartości pomiarowej po wyłaczeniu zespolu napędowego. Drugi to czas spadku ciśnienia poniżej określonej wartości i jego powrotu do tej wartości w czasie ruchu silnika hydraulicznego. Proponowana metoda daje możliwość bieżacej oceny stanu technicznego lotniczego napędu hydraulicznego, jest szybka i bezkosztowa.

Stowa kluczowe: stan techniczny, lotniczy napęd hydrauliczny, parametr kontrolny, ciśnienie 
Theoretical issues associated with the evaluation of the technical condition...

Teoretyczne aspekty oceny stanu technicznego lotniczego napeddu hydraulicznego...

\section{Introduction}

For all hydraulic drives, the cost-efficiency of their operation substantially depends on whether or not its current technical condition can be evaluated and whether future alterations of that conditions can be predicted with sufficient likelihood. Operation of avionic hydraulic drive installed on board of aircrafts is subjected to sophisticated conditions; therefore, various processes and factors affect its condition in diverse degrees. Destructive processes primarily lead to an increase of play between components of plunger and barrel mating assemblies. Increased play enables formation of critical clearances (leakage paths), which entails changes in flow rates and deteriorates dynamic parameters of the driven subassemblies (ailerons, elevators, flaps, undercarriage, decelerons).

Importance of aircraft functions triggered by the avionic hydraulic drive (it directly affects the driving unit operability, the system associated with piloting and steering as well as the components responsible for takeoff and landing operations) entails the need to provide the aircraft crew with quick and reliable information about the current technical condition of the avionic hydraulic drive.

Historically, the technical condition of avionic hydraulic drives was established during ground tests, according to the schedule of the aircraft maintenance operations while the drive was supplied from a stationary hydraulic power pack of the airfield. Such ground tests convey reliable information about the technical condition of the avionic hydraulic drive. Nevertheless, they are carried out only from time to time, which is insufficient to provide the user with quick feedback on the current technical condition of the drive. In addition, avionic hydraulic drives of most aircrafts are objects that are hardly susceptible to troubleshooting operations. Identification of their technical condition is sophisticated and accuracy of the result evaluation is really poor. Due to the above reasons, the maintenance personnel is frequently unable to identify the current technical condition of an avionic hydraulic drive. On the other hand, improvement of hydraulic drives susceptibility to troubleshooting attempts is quite expensive. Thus, the alternative and cost-efficient solution should assume that the troubleshooting method must benefit form measurable signals typically issued by avionic hydraulic drives.

The easiest available source of information suitable for avionic hydraulic drives to assess their technical condition is the internal pressure built-up in drives. Pressure and its parameters are inevitably associated with time. Aircrafts are provided with Flight Data Recorders (FDR) that are meant to keep records of flight parameters, data acquired from on-board instruments as well as systems and activities of the aircraft crew. With regard to the hydraulic drive, the parameter which is most frequently (or exclusively) recorded by the FDR "black box" is the waveform for pressure variations. Thus, it is the parameter which can serve as a standardized output signal issued by the hydraulic drive and analysis of the pressure variations may enable the maintenance personnel to assess the technical condition of avionic hydraulic drives as entire units. 
The study is intended to disclose theoretical issues that underlie the possibility to use information from unbiased means of aircraft flight control to assess the technical condition of avionic hydraulic drives on a current basis.

\section{Theoretical background for identification of the technical condition of avionic hydraulic drives on the basis of information from means for unbiased flight control of aircrafts}

Past experience demonstrates that among all commonly known physical phenomena affecting the technical condition of hydraulic units, the following can be distinguished as the most important ones [3, 4]:

- mechanical deterioration of hydraulic plunger and barrel mating assemblies due to abrasive and erosive wear of their working surfaces,

- fatigue wear of individual components exposed to the impact of dynamic loads,

- ageing of materials, in particular sealing and packing stuff of any type made of elastomeric rubber, caused by various substances used for operation of the units. First and foremost, the foregoing phenomena lead to an increase of the friction forces and of play between the components of the hydraulic plunger and barrel mating assemblies. Consequently, increased play and surface damages of hydraulic plunger and barrel mating assemblies result in formation of critical clearances (leakage paths), which entails changes in flow of the hydraulic fluid and deterioration in the dynamic performance of the driven actuator.

Thus, the most general assumption can be made that the deterioration degree of avionic hydraulic drives is an infinitely continuous function and changes during the entire lifetime of the subassembly, but it can be evaluated from variations of pressure and flow rates due to internal leaks. Hence, current assessment of technical condition demonstrated by an avionic hydraulic drive can benefit from information about variations of pressure inside the drive when the driven actuators (ailerons, elevators, flaps, undercarriage, decelerons) make movements, as well as from drop of pressure inside the hydraulic drive after the driving module of the hydraulic pump is switched off. The indispensable provision for that is keeping records on pressure variation across the avionic hydraulic drive by the Flight Data Recorder (FDR). The parameters that can serve as criteria for evaluation of the technical condition may include the duration of pressure drop below a specific threshold and restoration of the pressure up to that threshold when the hydraulic motor is running (the associated actuator of the aircrafts is making a movement) as well as duration of the pressure drop in the avionic hydraulic drive from the upper limit of measurements down to the lower limit of measurements after the driving unit is switched off. These time intervals shall serve as verification criteria for that drive. Fig. 1 presents an example of a graph for pressure variations in the avionic hydraulic drive downloaded from the Flight Data Recorder of a military jet airplane. One has to pay attention to the $t_{p s}$ time that stands for duration of pressure variations in that drive after movement of the hydraulic motor (aircraft actuator) and the $t_{\mathrm{sc}}$ time that denotes duration of the pressure drop from the upper limit of measurements to the lower limit of measurements after the driving unit is switched off (motor runoff time). 
Theoretical issues associated with the evaluation of the technical condition... Teoretyczne aspekty oceny stanu technicznego lotniczego napeddu hydraulicznego...

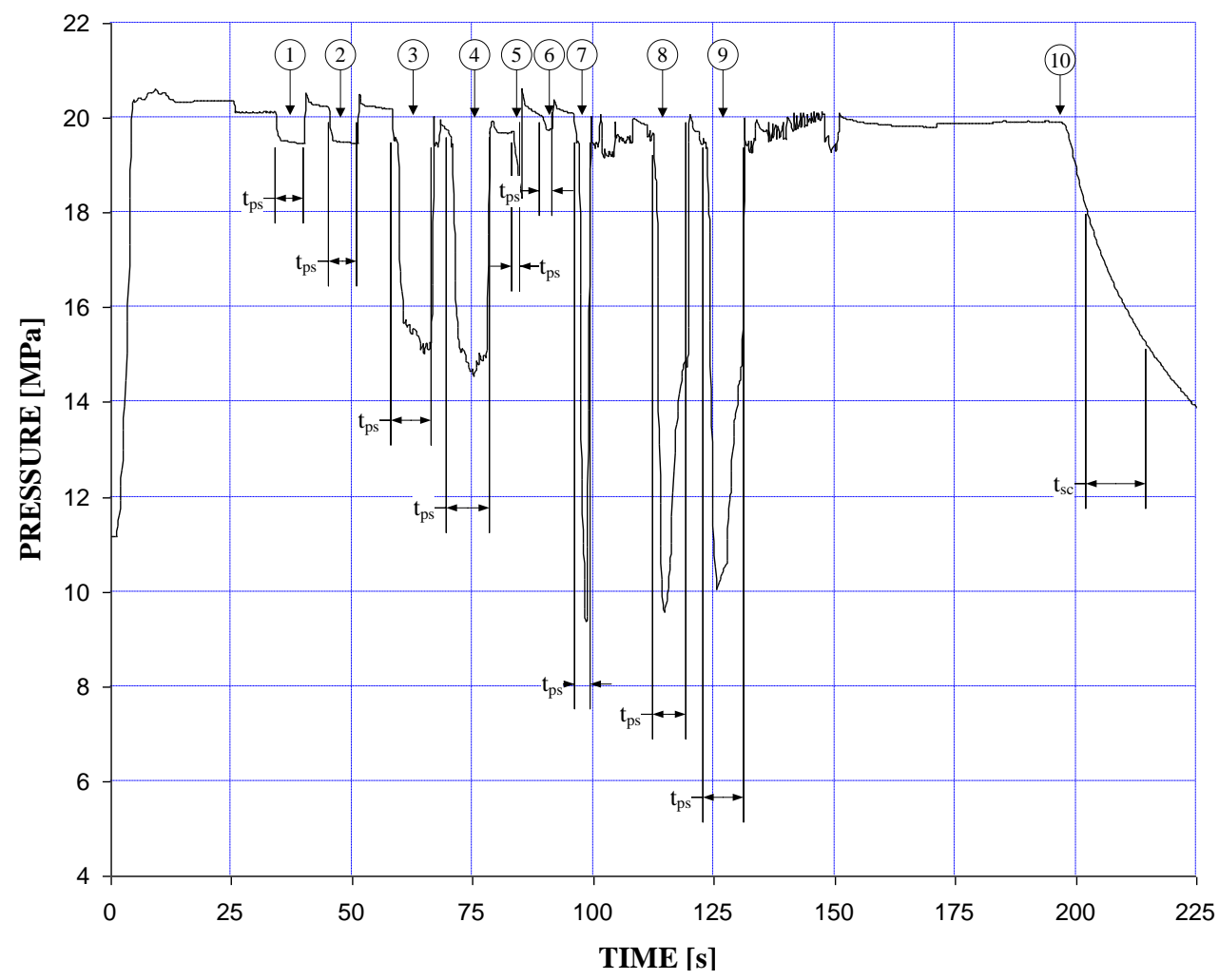

Fig. 1 Example of waveforms for variation of pressure in an avionic hydraulic drive stored in the Flight Data Recorder (FDR).

1) movements of the rudder (flight in a tight bend); 2) movements of the elevator (barrel roll) 3) repositioning of wings to the position of $60^{\circ}$; 4) repositioning of wings to the position of $30^{\circ}$; 5) activation of decelerons; 6) activation of flaps; 7) lowering of undercarriage; 8) retraction of undercarriage and flaps; 9) lowering of undercarriage and activation of flaps; 10) engine shutdown (the hydraulic pump drive) on the ground.

Duration of pressure changes (drops) in avionic hydraulic drives depends on rates and amounts of internal leaks from all hydraulic subassemblies associated with that drive. Internal leaks are determined by design clearances in hydraulic plunger and barrel mating assemblies. Design clearances (play) between mating surfaces of hydraulic components result from the wear and tear process. The higher the design clearance exists between mating surfaces (plunger and barrel assemblies) of hydraulic parts, the more hydraulic fluid leaks through these gaps (flow rates of internal leaks subject to increase) and, in consequence, the time necessary to change hydraulic pressure (make a motion of the aircraft actuator) with the running engine extends as well. 
Prior to the beginning of the technical condition evaluation of an avionic hydraulic drive, one has to determine boundary limits for the control parameter of that drive with the use of analytic methods.

Pressure in an avionic hydraulic drive is associated with rates of flow through internal gaps. Flow rates of internal leaks are directly proportional to pressure drops across these gaps, which is expressed by the equation:

$$
Q_{n}=q_{v} p,
$$

where:

$Q_{n}-$ flow rates of internal leaks $\left[\mathrm{m}^{3} / \mathrm{s}\right]$;

$q_{v}-$ coefficient of internal leak rates for drive subassemblies $\left[\mathrm{m}^{5} / \mathrm{Ns}\right]$;

$p-$ pressure in the avionic hydraulic drive [MPa].

Movement of driven actuators (ailerons, elevators, flaps, undercarriage, decelerons) is triggered by a rapid jump (step input function) of flow rate in a specific module of the hydraulic drive and can be then split into two phases. The first phase comprises an increase of the hydraulic pressure up to the limit corresponding to the static external load affecting that module of the hydraulic drive, which, in turn, commences the second phase which begins when the pressure limit corresponding to the static load is reached.

The equation for flow balance during the first phase upon the step input function of flow adopts the following form [2]:

$$
Q_{p}-q_{v} p_{z c}-c \frac{d p_{z c}}{d t}=0
$$

where:

Qp - delivery of the hydraulic pump $\left[\mathrm{m}^{3} / \mathrm{s}\right]$;

$q_{v}-$ coefficient of the internal leak rated for subassemblies of the hydraulic drive $\left[\mathrm{m}^{5} / \mathrm{Ns}\right]$;

$p_{z c}-$ pressure jump in the avionic hydraulic drive [MPa];

$c$ - hydraulic capacitance of the drive $\left[\mathrm{m}^{5} / \mathrm{N}\right]$;

$t \quad-$ time [s].

The equation (2) leads to the following inhomogeneous differential equation for pressure variations:

$$
\frac{c}{q_{v}} \frac{d p_{z c}}{d t}+p_{z c}=\frac{Q_{p}}{q_{v}}
$$

The homogeneous equation adopts the form:

$$
\frac{c}{q_{v}} \frac{d p_{z c}}{d t}+p_{z c}=0
$$


Theoretical issues associated with the evaluation of the technical condition...

Teoretyczne aspekty oceny stanu technicznego lotniczego napedu hydraulicznego...

which leads to:

$$
\frac{d p_{z c}}{p_{z c}}=-\frac{q_{v}}{c} d t
$$

Integration of both sides of the equation (5) results in the formula:

$$
\ln p_{z c}=-\frac{q_{v}}{c} t+\ln K
$$

where $\mathrm{K}$ is the integration constant. For $t=0$ and $p_{z c}=0$, the constant is

$$
K=-\frac{Q_{p}}{q_{v}}
$$

The indefinite integral for the inhomogeneous equation is defined by the relationship:

$$
p_{z c o}=K \exp \left(-\frac{q_{v}}{c} t\right)
$$

The definite integral for the inhomogeneous equation is sought in the form of the $\Gamma$ constant. Upon substitution of $\Gamma$ to the equation (3), the following formula is achieved:

$$
\Gamma=\frac{Q_{p}}{q_{v}}=p_{z c}
$$

The resolution for the equation (2) is expressed as the sum of two integrals: the indefinite integral for the homogeneous equation and the definite integral for the inhomogeneous equation:

$$
p_{z c}=K \exp \left(-\frac{q_{v}}{c} t\right)+\frac{Q_{p}}{q_{v}}
$$

Pressure variations in the hydraulic avionic drive are expressed by the formula:

$$
p_{z c}=\frac{Q_{p}}{q_{v}}\left[1-\exp \left(-\frac{q_{v}}{c} t\right)\right],
$$

which makes it possible to derive time of the pressure jump caused by the static load affecting the avionic hydraulic drive:

$$
t_{r}=\frac{q_{v}}{c} \ln \frac{Q_{p}}{Q_{p}-p_{u} q_{v}} .
$$

where $p_{u}$ stands for the value of pressure associated with the static load acting during steady motion and is defined by the relationship: 


$$
p_{u}=\frac{F_{z} \cdot l-\rho_{w} \cdot \omega_{s}}{q_{c h}}
$$

where: $\omega_{s}-$ angular speed of the hydraulic motor $[\mathrm{rad} / \mathrm{s}]$;

$q_{c h}-$ unit volume of the hydraulic motor $\left[\mathrm{m}^{3} / \mathrm{rad}\right]$;

$F_{z}-$ static force caused by the external load;

$l \quad-$ stroke (travel) of the motor piston rod [m];

$\rho_{w}-$ coefficient of viscous resistance [Nms].

After the pressure threshold associated with the static load is achieved, the equation for flow balance adopts the following form [2]:

$$
c \frac{d p_{z c}}{d t}=Q_{p}-q_{v} p_{z c}-q_{c h} \omega_{s}
$$

The equation for motion of the hydraulic motor which drives steering facilities and subassemblies related to takeoff and landing operations (ailerons, elevators, flaps, undercarriage, decelerons) is as below:

$$
I \frac{d \omega_{s}}{d t}=p_{z c} q_{c h}-F_{z} l-\rho_{w} \omega_{s}
$$

where: $I-$ moment of inertia for the moving part of the hydraulic motor $\left[\mathrm{kgm}^{2}\right]$.

Pressure variations in the hydraulic system after the pressure threshold associated with the static load is achieved can be expressed by the equation below:

$$
\frac{I \cdot c}{q_{c h}^{2}} \cdot \frac{d^{2} p_{z c}}{d t^{2}}+\frac{\rho_{w} \cdot c+q_{v} \cdot I}{q_{c h}^{2}} \cdot \frac{d p_{z c}}{d t}+p_{z c}=p_{u}
$$

The equation (13) transformed to the equation in the normalized form adopts the form:

$$
T^{2} \frac{d^{2} \theta}{d t^{2}}+2 \varsigma T \frac{d \theta}{d t}+\theta=1
$$

where:

$$
\begin{gathered}
T=\frac{\sqrt{I \cdot c}}{q_{c h}} \\
\varsigma=\frac{\rho_{w} \cdot c+q_{v} \cdot I}{2 q_{c h} \sqrt{c \cdot I}}
\end{gathered}
$$


Theoretical issues associated with the evaluation of the technical condition...

Teoretyczne aspekty oceny stanu technicznego lotniczego napeddu hydraulicznego...

$$
\theta=\frac{p_{z c}}{p_{u}} .
$$

After the Lapalce transformation of (14) one can obtain the transform for the nondimensional pressure (pressure value in the time domain). The expression which defines the pressure in the time domain makes it possible to obtain the expression describing pressure variations in the system of the avionic hydraulic drive after repositioning of the hydraulic distributor slider:

$$
p_{z c}=p_{u}+\frac{Q_{p}-p_{u} \cdot q_{v}}{c \cdot \omega} e^{-\varsigma \frac{t-t_{r}}{T}}
$$

The frequency of pressure oscillations in the hydraulic system with a rotating hydraulic motor can be calculated as below [2]:

$$
\omega_{r o}=\sqrt{\frac{q_{c h}^{2}}{c \cdot I}-\left(\frac{I \cdot q_{v}+\rho_{w} \cdot c}{2 \cdot I \cdot c}\right)^{2}}
$$

whilst the frequency of pressure oscillations in the hydraulic system with a linear hydraulic motor (to and fro piston motion) adopts the form [2]:

$$
\omega_{r l}=\sqrt{\frac{F_{t}^{2}}{c \cdot m}-\left(\frac{m \cdot q_{v}+\rho_{s} \cdot c}{2 \cdot m \cdot c}\right)^{2}}
$$

where: $F_{t}$ - surface of the cylinder piston (piston /linear hydraulic motor)

The relationship (15) makes it possible to define pressure variations in an avionic hydraulic drive while the hydraulic motor is running:

$$
t_{p s}=t_{r}+\frac{\varsigma}{T} \ln \frac{c \cdot \omega\left(p_{z c}-p_{u}\right)}{Q_{p}-p_{u} \cdot q_{v}}
$$

Substitution of parameter values to equations (9) and (16) enables determination of the limit threshold for duration of the pressure jump in the avionic hydraulic drive while the hydraulic motor is running.

Flow in the drainage line of the hydraulic drive (after the driving motor of the hydraulic pump is switched off) caused by change of the fluid volume inside the hydraulic accumulator (measurement of pressure supplied to the Flight Data Recorder /FDR) can be described in the following way:

$$
Q_{n}=\frac{V}{E} \frac{d p}{d t}
$$

where: $V-$ volume of the oil part of the hydraulic accumulator $\left[\mathrm{m}^{3}\right]$,

$E$ - modulus of the volumetric elasticity for hydraulic fluid [Pa], 
$p$ - pressure change across the accumulator [MPa],

$t$ - duration of the pressure change across the hydraulic accumulator [s]. Pressure variations across the accumulator depend also on internal leak rates (the relationship (1)) in subassemblies of the avionic hydraulic drive. Flow rate in the drainage line of the hydraulic drive caused by change of the fluid volume inside the hydraulic accumulator (after the driving motor of the hydraulic pump is switched off) can be defined by the following formula:

$$
q_{v} \cdot p=\frac{V}{E} \frac{d p}{d t}
$$

After separation of variables, the equation (18) can be transformed into the following form:

$$
\int_{p_{G}}^{p_{D}} \frac{d p}{p}=\frac{E \cdot q_{v}}{V} \int_{0}^{t} d t
$$

Integration of both sides of the equation leads to the relationship which makes it possible to determine duration of the pressure drop in the hydraulic drive after the driving motor of the hydraulic pump within the drive is switched off.

$$
t_{s c}=\frac{V\left(\ln p_{G}-\ln p_{D}\right)}{E \cdot q_{v}}
$$

Substitution of the parameter values to the equation (20) leads to determination of the boundary limit for the time of pressure drop in the hydraulic drive after the driving motor of the hydraulic pump within that drive is switched off.

\section{Prediction of the technical condition attributable to a hydraulic drive on the basis of information acquired from means for unbiased flight control.}

Deterioration of the control parameter for an avionic hydraulic drive (accumulation of effects caused by wear and tear of mating surfaces in that drive - increase of the duration time necessary to allow pressure changes in an avionic hydraulic drive while the hydraulic motor is running or reduction of the time interval necessary for pressure drop in the hydraulic drive after the driving motor of the hydraulic pump within that drive is switched off) denoted as $y$ and being a function of time is referred to as the deterioration rate for that parameter, i.e. $v=\frac{d y}{d t}=f(y)$. When the rate of changes exercised by the control parameter $y$ is constant (accumulation of effects from wear and tear - increase of internal leak rates in the drive), such a rate of changes can be expressed by means of the following relationship [1]:

$$
v=\frac{d y}{d t}=c+k y \text {, }
$$


Theoretical issues associated with the evaluation of the technical condition...

Teoretyczne aspekty oceny stanu technicznego lotniczego napeddu hydraulicznego...

where: $k=\operatorname{tg} \varphi-\varphi$ is the inclination angle (slope) of the curve for variation of the control parameter,

$c \quad$ - displacements in variations of the control parameter.

Transformation of the foregoing relationship with further integration of its both left and right side respectively by time and by increment of the wear effect and the assumption that after the operation time of $t_{l}$ the average change of the control parameter is $y_{1}$ make it possible to obtain the following formulas [4]:

$$
\begin{aligned}
& t-t_{1}=\frac{1}{k} \ln \frac{c+k y}{c+k y_{1}}, \\
& y=\left(y_{1}+\frac{c}{k}\right) e^{\left(t-t_{1}\right) k}-\frac{c}{k} .
\end{aligned}
$$

The substitution $\frac{1}{k \ln e}=A$ and $\frac{c}{k}=h$ and transition from the natural logarithm to the decimal one in the foregoing expression leads to the following formula:

$$
y=\left(y_{1}+h\right) 10^{\frac{t-t_{1}}{A}}-h .
$$

The $A$ coefficient defines the shape of the curve for determination of the control parameters for the avionic hydraulic drive whilst $h$ is the coefficient of the curve displacement (defines location of the curve).

The upper limit for the process of the control parameter deterioration for an avionic hydraulic drive can be determined from the equation:

$$
y_{\text {max }}=\left(y_{1}+\sigma_{1}+h\right) 10^{\frac{t-t_{1}}{A}}-h,
$$

whilst the lower limit is defined by the formula:

$$
y_{\min }=\left(y_{1}-\sigma_{1}+h\right) 10^{\frac{t-t_{1}}{A}}-h,
$$

where: $y_{\max }-$ current upper limit,

$y_{\min }-$ current lower limit,

$\sigma_{1}-$ mean square deviation for deterioration of the functional parameter at the moment $t_{1}$.

The $A$ and $h$ coefficients can be determined from the following relationships:

$$
A=\frac{t_{2}-t_{1}}{\lg \frac{\sigma_{2}}{\sigma_{1}}}, \quad h=\frac{y_{2}-y_{1} \frac{\sigma_{2}}{\sigma_{1}}}{\frac{\sigma_{2}}{\sigma_{1}}-1},
$$


where: $y_{2}-$ average change of a certain functional parameter at the moment of $t_{2}$, $\sigma_{2}-$ mean square deviation of that parameter at the moment of $t_{2}$.

When the values of the statistical moments, i.e. the expected value $m_{y}(t)$ and the mean square deviation for the specific control parameter of the avionic hydraulic drive are known, it is possible to calculate the average change $y_{s r}$ of that parameter and the confidence intervals for deterioration of that parameter $[3,4]$.

\section{Conclusions}

Information about the technical condition of avionic hydraulic drives is continuously collected by aircraft users during operation thereof and is then used to set up procedures that govern maintenance of these drives to keep them in sound operating standing. The pressure in hydraulic drives is the information carrier that can be acquired in the easiest way and is useful for current evaluation of the technical condition attributable to avionic hydraulic drives. The analysis of pressure variations may serve as the outset to evaluate the technical condition of an avionic hydraulic drive as a whole.

Pressure and its attributes vary in time, thus these two parameters are linked in an inseparable way. It is the relationship that can be benefited when information about the hydraulic drive is acquired from means for unbiased control of aircrafts.

There are two control parameters that are provided by the means of unbiased flight control and convey the highest trustworthiness and troubleshooting content. The first one is the duration of pressure drop across the avionic hydraulic drive after switching the driving unit off with the span from the upper measured limit to the lower limit. The second one is the total time of the cycle when pressure drops below the specific threshold and then is restored to that threshold during a movement of a hydraulic motor (an on-board aircraft actuator). The suggested method enables quick and real-time evaluation of the technical condition attributable to avionic hydraulic drives.

Prediction of future alterations to the technical condition of avionic hydraulic drives consists in comparison between actual duration of the pressure change with the limit threshold for that time interval.

Duration of pressure changes in avionic hydraulic drives at any moment of their lifetime can be described by the Gaussian distribution with the assumption that the scheme for deterioration to the duration of pressure changes combines full probabilistic characteristics of immunity to wear processes demonstrated by the hydraulic plunger and barrel mating assemblies. The important issue related to determination of the current value for duration of pressure changes is the fact that the process of its deterioration is quite close to the average scheme. It is why practical benefits from the function of the density for duration of pressure changes is only possible when actual plots are available for changes in duration of pressure changes as the function of the system lifetime. When the actual variations for duration of pressure changes in avionic hydraulic drives are known, it is possible to compute the expected value $m_{y}(t)$, the mean square deviation $\sigma_{y}(t)$, the average 
Theoretical issues associated with the evaluation of the technical condition...

Teoretyczne aspekty oceny stanu technicznego lotniczego napędu hydraulicznego...

duration of pressure changes and confidence interval for the process of that parameter during the system lifetime.

According to the suggested method, the assessment process for current technical condition of avionic hydraulic drives consists of three basic phases:

1) determination of boundary limits for duration of pressure changes in hydraulic drives (from the relationships 16 and 20),

2) acquisition of information from means for unbiased control of the aircraft with regard to variation of pressure in the hydraulic system,

3) comparison between actual durations of pressure changes in the hydraulic drive and the limit thresholds with further analysis of the nature and reasons for deviations.

The foregoing method suggested for current (real-time) evaluation of the technical condition demonstrated by avionic hydraulic drives is quick and needs virtually no expenses.

\section{References}

[1] Cieciura M, Stasierski J., Elementy teorii decyzji statystycznych, Wydawnictwo Wojskowej Akademii Technicznej, Warszawa 1974. [Constituents of the theory for statistic decisions, Publishing House of the Military University of Technology, Warsaw, 1999];

[2] Tomczyk J., Modele dynamiczne elementów i uktadów napędów hydrostatycznych, Wydawnictwo Naukowo-Techniczne, Warszawa 1999. [Dynamic models for components and circuits of hydrostatic drives, Publishing House for Technology and Science, Warsaw, 1999];

[3] Ułanowicz L., Outline of the method to operate hydraulic drives by their technical condition with continuous monitoring of their parameters, Polish Journal of Environmental Studies, Vol. 18, No 4B, str. 206 $\div 211$, 2009r.

[4] Ułanowicz L., Violation of the steady-state friction behaviour of a precise hydraulic pair due to imbalanced radial hydrostatic force, Journal of Konbin No 2,3(14,15), str. 341-358, 2010.

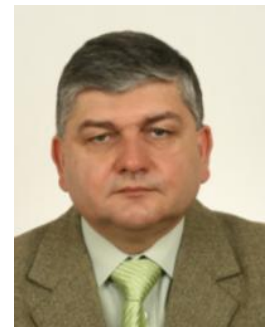

Dr hab. inz. Leszek Ulanowicz, absolwent Wojskowej Akademii Technicznej $w$ zakresie samolotów i śmiglowców. Wieloletni pracownik naukowo-badawczy w Instytucie Technicznym Wojsk Lotniczych. Pracuje w Zakładzie Samolotów i Śmigłowców na stanowisku adiunkta. Gtówne kierunki działalności naukowej to: lotnicze napędy hydrauliczne $i$ ich systemy sterowania oraz regulacji, niezawodność $i$ eksploatacja systemów technicznych, badania naziemne i w locie statków powietrznych. Jest autorem $i$ wspótautorem 62 prac naukowych (monografii, artykułów, referatów na konferencjach $i$ seminariach naukowych). Kierownik kilku projektów badawczo-rozwojowych. 